\title{
LOKALITAS SASAK DALAM NOVEL GURU DANE DAN GURU ONYEH KARYA SALMAN FARIS
}

\author{
Lalu Nasrulloh \\ Institut Agama Islam Hamzanwaddin NW Pancor, Lombok Timur, NTB \\ laluaru190@gmail.com
}

\begin{abstract}
ABSTRAK
Penelitian ini bertujuan untuk mendeskripsikan (1) wujud lokalitas Sasak dalam novel Guru Dane dan Guru Onyeh karya Salman Faris, dan (2) fungsi lokalitas Sasak dalam membangun cerita secara keseluruhan pada novel Guru Dane dan Guru Onyeh karya Salman Faris. Jenis penelitian ini adalah kualitatif. Subjek penelitian ini novel Guru Dane dan Guru Onyeh karya Salman Faris dan teori yang digunakan adalah teori sosiologi sastra. Keabsahan data diperoleh dengan uji triangulasi teori. Data dianalisis dengan teknik deskriptif kualitatif, yakni mendeskripsikan, kategorisasi, inferensi, dan penyajian data. Hasil penelitian ini menunjukkan hal-hal sebagai berikut. Pertama, wujud lokalitas Sasak dalam novel Guru Dane dan Guru Onyeh tercermin pada beberapa unsur, yaitu: (1) lokasi atau tempat, (2) sistem kemasyarakatan suku Sasak, (3) sistem kepercayaan (agama) dan mitos, (4) kesenian Sasak, (5) penggunaan bahasa Sasak, (6) sistem mata pencaharian hidup masyarakat suku Sasak, dan (7) sistem teknologi dan peralatan masyarakat suku Sasak. Kedua, fungsi lokalitas Sasak dalam membangun cerita secara keseluruhan, yang paling dominan mempengaruhi adalah latar tempat, penggunaan bahasa Sasak (diksi), serta yang terakhir adalah nama-nama tokoh yang mencerminkan ciri khas orang Sasak, seperti Amaq Tembiengbieng, Jero Mihram, Temelak Mangan, dan Guru Dane.
\end{abstract}

Kata Kunci: lokalitas, Sasak, sosiologi sastra

\section{SASAK LOCALITY IN NOVEL GURU DANE AND GURU ONYEH BY SALMAN FARIS}

\begin{abstract}
This study was aimed to describe (1) the form of Sasak locality in novel Guru Dane dan Guru Onyeh by Salman Faris, and (2) the function of Sasak locality in the process of building context of the whole story in the novel Guru Dane dan Guru Onyeh by Salman Faris. The research is qualitative research. The subject of this research was novel Guru Dane dan Guru Onyeh by Salman Faris. The data of this research was focused on the problem of the form and the function of Sasak locality in the novel Guru Dane dan Guru Onyeh which used theory of sociology literature. The validity of the data is obtained by the theory of triangulation test. The data was analyzed by descriptive qualitative, which are description, categorization, inferention, and data presentation. The result of this research shows this fact. First, Sasak locality in the novel Guru Dane dan Guru Onyeh is showed in the several elements, such as: (1) the location, (2) the social system of the Sasak, (3) the belief system (religion) and myth, (4) art of the Sasak, (5) the use of Sasak language, (6) the livelihoods live system of the Sasak, and (7) the technology system and equipment of the Sasak. Second, function of Sasak locality which could build story as a whole, the most dominant effect is the setting, the use of Sasak language (diction), and the last is the name of figure such as Amaq Tembiengbieng, Jero Mihram, Temelak Mangan, and Guru Dane.
\end{abstract}

Keywords: locality, Sasak, sociology literature 


\section{PENDAHULUAN}

Ketika mendengar kata Lombok, pasti yang pertama terbersit di dalam benak pendengarnya adalah pantai dan Gunung Rinjani. Padahal, tidak hanya itu yang dimiliki oleh daerah yang dijuluki dengan pulau seribu masjid tersebut. Lombok yang merupakan bagian dari wilayah Indonesia yang terletak di daerah Provinsi Nusa Tenggara Barat tersebut, memiliki keindahan alam yang sangat memesona serta dibaluti dengan tradisi dan budaya yang sangat beragam. Warsito (via Salam, 1992: vii) mengungkapkan dalam sambutannya bahwa daerah Nusa Tenggara Barat yang di dalamnya termasuk Lombok, dianugerahi Tuhan keindahan alam yang sangat mempesona, berbagai macam flora dan fauna, begitu juga dengan adat-istiadatnya, kesenian, bahasa, dan sebagainya. Bahasa yang digunakan oleh masyarakat suku Sasak adalah bahasa Sasak, yang banyak dipengaruhi oleh bahasa Bali, seperti kata tiang, titiang, pakulan, dan lain sebagainya (Sumadi, 2013: 31).

Begitu pula halnya dengan kesenian yang menjadi tradisi khas masyarakat suku Sasak yang banyak dipengaruhi oleh budaya Bali, seperti salah satunya adalah kesenian gendang beleq. Kesenian gendang beleq ini dapat dipentaskan berdiri ataupun duduk, serta berfungsi untuk mengiringi upacara perkawinan khususnya pada tahap upacara nyongkolan. Ke-senian maupun bahasa tidak ketinggalan adanya pengaruh Hindu. Hal ini dapat dibuktikan dengan isi tulisan pada prasasti maupun bahasa yang terpakai/tertulis pada daun lontar di Pulau Lombok (Wacana, 2002:14). Selanjutnya mengenai sejarah Lombok, mulai dari kedatuan Selaparang sampai sejarah ekspansi Raja Karangasem Bali yang mendirikan kerajaan di Mataram. Peristiwa ini terjadi pada tahun 1842, Raja Mataram menaklukkan kerajaan-kerajaan seperti Kerajaan Pegesangan dan Kahuripan. Kemudian setelah tahun 1843, Raja Mataram memindahkan Ibu Kota Kerajaan Mataram ke Cakranegara dengan nama kerajaan Ukir Kawi (Sumadi, 2013: 36).

Sejarah bangsa Sasak ini bisa dikatakan sangat kelam, tetapi harus tetap diungkap sebagai pengalaman untuk menciptakan peradaban baru. Ma'arif (2015: 49) mengatakan terkait dengan hal tersebut bahwa "dalam sejarah kepahitan harus dikatakan dan dibongkar secara berani dan bertanggung jawab, sekalipun menelanjangi diri sendiri". Sebuah kecerobohan sejarah, jika orang berupaya menutupi kepahitan dengan bungkus yang serba manis agar bernuansa menghibur.

Budaya lokal (lokalitas) yang dimiliki oleh bangsa Sasak ini sangat beragam. di dalam kebudayaan daerah tentu mengandung kearifan lokal yang menjadikan suatu daerah tersebut memiliki peradaban yang dapat dilestarikan. Kearifan lokal (local genius) yang menjadi jembatan atau penghubung terbentuknya kebudayaan nasional bahkan internasional. Ratna (2011: 94) mengutarakan terkait dengan hal tersebut.

Kearifan lokal merupakan semen pengikat berbagai bentuk kebudayaan yang sudah ada sehingga disadari keberadaannya. Kearifan lokal berfungsi memberikan sumbangan terhadap kebudayaan yang lebih luas, baik nasional maupun internasional.

Kearifan lokal ini selain dapat menjadi penghubung terbentuknya kebudayaan nasional maupun internasional, juga dapat dijadikan sebagai pedoman penyelesaian konflik antarsuku. Seperti yang disampaikan oleh Ma'arif (2015: 54) bahwa gesekan antarsuku akan dapat diselesaikan dengan berpedoman kepada kearifan lokal di bawah payung kearifan nasional. Maka, kearifan lokal diharapkan supaya terpelihara dan terus dikembangkan secara optimal. Lokalitas pada konteks kekinian dapat menjadi filter arus globalisasi yang semakin mengkhawatirkan. Maka dari itu, dengan adanya kesadaran budaya dari para pelaku budaya mampu menepis ancaman global tersebut.

Kebudayan daerah dan lokalitas tercermin dalam unsur-unsur kebudayaan, seperti halnya yang utarakan oleh Kluckhon (via Geertz, 1973: 4) mengemukakan sebagai berikut:

1) the total way of life of people; 2) the social legacy the individual acquires from his group; 3) a way of thinking, feeling, and beliving; 4) an abstraction from behavior; 5) a theory on part of the anthropologist about the way in which a group of people in fact behave; 6) a 
store house of people learning; 7) a set of standirized orientations to recurrent problem; 8) learned behavior; 9) a mechanism for the normative regulation of behavior; 10) a set of techniques for adjusting both to the external enviroment and to other man; 11) a precipitate of history.

Sebuah kebudayaan merupakan suatu hal yang lengkap, meliputi segala aspek kehidupan, seperti cara keseluruhan manusia menjalani kehidupan, warisan sosial yang diperoleh seorang dari kelompoknya, cara berpikir, merasakan, dan berkeyakinan, sebuah abstraksi perilaku, sebuah cabang teori antropologi yang mengambarkan cara suatu kelompok masyarakat berperilaku secara nyata, merupakan wadah pembelajaran, seperangkat orientasi-orientasi standar terhadap masalah yang sedang berlangsung, sarana pembelajaran terhadap perilaku, mekanisme penataan norma dalam bertingkah laku, seperangkat teknik untuk menyesuaikan diri terhadap lingkungan eksternal dan orang lain (penduduk asli), dan merupakan endapan sejarah.

Lain halnya dengan Triandis (via Berns, 2004: 126) yang mengemukakan tentang budaya, yaitu:

Culture include the knowledge, beliefs, arts, morals, law, custom, and traditions acquered by members of a society. Culture encompasses the way people have learned how to adapt to their enviroment, their assumtions about the way the world is, and their beliefs about the way people should act.

Kebudayaan meliputi pengetahuan, keyakinan, seni, moral, hukum, adat, dan tradisi yang diperoleh oleh anggota masyarakat. Kebudayaan meliputi cara orang-orang belajar bagaimana beradaptasi terhadap lingkungan hidup mereka, serta sistem keyakinan mereka terhadap bagaimana seharusnya orang bertindak.

Lokalitas pada umumnya dipahami sebagai sesuatu yang berada dalam suatu daerah dengan cakupan lokal dan batasan lokal. Akan tetapi, batasan lokalitas itu tidak mencakup aspek spasial semata, seperti halnya desa, kota, kampung, atau lokalitas lainnya. Hartono (2015: 51) menyebutkan bahwa warna lokal atau lokalitas merupakan ciri khas tertentu dari masyarakat setempat yang berkaitan dengan budaya tempatan. Namun, yang termasuk dalam batasan lokalitas ini seperti pranata sosial, serta unit-unit budaya yang ada dalam sekup lokalitas tersebut, sehingga penekanan mengenai lokalitas itu sendiri bisa pada sejarah lokalnya, budaya lokal, dan kearifan lokal. Dengan demikian, apa yang disebut sebagai sejarah lokal akan selalu berkaitan dengan suatu tempat dan ruang, sehingga sejarah lokal berarti sejarah suatu tempat atau lokalitas dengan batasbatas yang telah ditentukan. Batasan-batasan ini bisa berupa sebuah suku, desa atau kota. Sayuti (2011: 7) mengatakan bahwa budaya lokal tertentu merupakan gugus-gagasan lokal yang bersangkutan. Begitu juga halnya Abrams (1981: 98) mengatakan bahwa lokalitas sebagai lukisan yang cermat mengenai latar, dialek, adat kebiasaan, cara berpakaian, cara berpikir, cara merasa, dan sebagainya yang khas dari suatu daerah tertentu yang terdapat dalam cerita.

Kaitannya dengan lokalitas dalam karya sastra, khususnya novel, ada yang disebut dengan tokoh dan latar cerita yang meliputi latar waktu, tempat, dan latar sosial. Dalam latar cerita tersebut, wujud lokalitas dominan terdapat pada latar sosial atau latar sosial budaya. Latar sosial budaya biasanya terwujud dalam tokohtokoh yang ditampilkan, sistem kemasyarakatan, adat istiadat, pandangan masyarakat, kesenian, benda-benda kebudayaan yang terungkap dalam karya sastra (Pradopo, 1987: 234). Dalam hal ini lokalitas Sasak sebagai bagian dari cerminan sosial budaya masyarakat suku Sasak memiliki berbagai macam wujud dan fungsi. Wujud lokalitas Sasak tercermin di dalam segala sisi kehidupan masyarakat, baik itu berupa unsur kepercayaan, adat-istiadat, unsur teknologi, maupun kesenian serta penggunaan bahasa yang dipakai oleh masyarakat untuk berinteraksi.

Lebih jauh, lokalitas dalam sastra tidak semata berkaitan dengan tema, namun juga latar yang menjadi ciri khas suatu daerah. Latar pesisir dan agraris misalnya membentuk budaya masyarakat dengan karakteristik berbeda. Seperti Sutarto (2004: 1) membagi budaya Jawa 
Timur dalam sub-sub kebudayaan, seperti budaya Arek, Mataraman, Tengger, Osing, Samin, dan Madura. Dalam karya sastra sub-sub kebudayaan ini dimanfaatkan oleh pengarang sebagai latar cerita dalam karya yang diciptakannya, seperti Ahmad Tohari dan Umar Kayam yang merefleksikan budaya Jawa dalam karyanya. Begitu pula halnya dengan Salman Faris yang mengusung budaya lokal Sasak dalam novel Guru Dane (2011) dan Guru Onyeh (2012).

Salman Faris yang merupakan warga masyarakat suku Sasak Lombok berusaha untuk menampilkan budaya lokal Sasak sebagai pemberi warna lokal dalam karya fiksinya. Dalam novel Guru Dane dan Guru Onyeh ini mampu memberikan warna terhadap keberadaan sastra khusus di daerah Lombok. Di dalamnya Salman Faris menggambarkan berbagai macam tradisi dan kebudayaan yang berkembang di masyarakat Sasak, baik sejarah, bahasa, adat dan tradisi, maupun perkakas kebudayaan masyarakat suku Sasak. Rosidi (1985: 27) mengungkapkan bahwa ketika mengumumkan lahirnya suatu angkatan terbaru tahun 60-an, menyebutkan salah satu ciri kuatnya angkatan tersebut adalah orientasi nilai-nilai budaya daerah. Penulisan novel yang berlatar belakang lokalitas mencapai puncaknya pada periode 1980 -an. Pada tahun tersebut, sastra (khususnya) novel Indonesia digairahkan oleh sesuatu yang disebut dengan warna lokal atau sensibilitas lokal (Kuntowijoyo, 1987: 133).

Berdasarkan apa yang diungkap oleh Kuntowijoyo di atas, ada kesaman dengan alternatif penciptaan yang dilakukan Salman Faris dalam novel Guru Dane dan Guru Onyeh. Dalam novel Guru Dane dan Guru Onyeh penuh dengan lokalitas kedaerahan Sasak. Penonjolan warna lokalitas kedaerahan Sasak ini menunjukkan bahwa Salman Faris dalam menciptakan karya sastra ingin kembali ke akar budaya daerah sebagai sumber kreatif dan inspirasinya. Seperti yang diutarakan oleh Sayuti (2011: 1) bahwa sastra Indonesia sulit untuk melepaskan diri dari unsur daerah atau lokalitas. Hal ini terjadi karena sastra Indonesia pada dasarnya adalah sastra lokal.

\section{METODE}

Jenis penelitian ini adalah penelitian kualitatif. Penelitian kualitatif merupakan suatu proses penelitian dan pemahaman yang berdasarkan pada metodologi yang menyelidiki suatu fenomena sosial dan masalah manusia. Denzin \& Lincoln (2005: 3) mengemukakan bahwa.

Qualitative research is a situated activity that locates the observer in the world. It consists of a set of interpretive, material practices that make the world visible. These practices transform the world. They turn the world into a series of representations, including field notes, interviews, conservations, photograps, recordings, and memos to the self.

Pendekatan atau teori yang digunakan dalam penelitian ini adalah teori sosiologi sastra, karena pendekatan ini berspektif bahwa dalam memahami, menganalisis, dan menilai sebuah karya sastra harus mempertimbangkan aspek kemasyarakatannya, dan sastra tidak dipandang sebagai sesuatu yang otonom, melainkain harus dipahami dalam hubungannya dengan kemasyarakatan. Pandangan sosiologi sastra juga menganggap sastra sebagai salah satu fenomena budaya (Wiyatmi, 2013: 5).

Sebagaimana halnya penelitian sastra lainnya, setting dalam penelitian ini berupa waktu dan tempat. Waktu penelitian ini dimulai dari bulan Oktober 2015 sampai bulan Januari 2016, yang bertempat di daerah Yogyakarta. Tahapan yang dilalui dalam penelitian ini dimulai dari bimbingan proposal, pembuatan laporan, dan penyajian laporan hasil.

Sumber data yang digunakan dalam penelitian ini adalah berupa sumber tertulis (dokumen). Menurut Lofland dan Lofland (via Moleong 2008: 157) bahwa sumber data utama dalam penelitian kualitatif ialah kata-kata dan tindakan, selebihnya adalah data tambahan seperti dokumen dan lain-lain.

Berdasarkan pendapat ahli di atas, maka sumber dalam penelitian ini adalah novel-novel karya Salman Faris yakni novel Guru Daneterbit tahun 2011, penerbit STKIP Hamzanwadi Press, tebal 458 halaman dan novel Guru Onyeh yang 
terbit tahun 2012, penerbit STKIP Hamzanwadi Press, tebal 398 halaman.

Teknik pengumpulan data yang digunakan dalam penelitian ini adalah dengan teknik pembacaan dan pencatatan (baca cata). Selayaknya pada penelitian kualitatif lainnya instrumen pengumpulan data yang digunakan dalam penelitian ini adalah peneliti sendiri ( $h u$ man instrument). Teknik pemeriksaan keabsahan data (dokumen) dalam penelitian ini adalah menggunakan teknik triangulasi teori. Teknik validitas ini beranggapan bahwa fakta tidak dapat diperiksa derajat kepercayaannya dengan satu teori atau lebih. Dengan teknik triangulasi ini juga dapat me-recheck temuannya dengan jalan membandingkannya dengan berbagai sumber, metode, dan atau teori (Moloeng, 2008: 331-332). Teknik analisis data yang digunakan dalam penelitian ini adalah analisis deskriptif kualitatif, yang mana model ini adalah upaya berlanjut, berulang, dan terus-menerus antara melakukan deskripsi data, kategorisasi, inferensi, dan penyajian data. Berikut pemaparan keempat tahap tersebut.

\section{HASIL DAN PEMBAHASAN \\ Wujud Lokalitas Sasak dalam Novel Guru Dane dan Guru Onyeh Lokalitas Sasak pada Tempat}

Pada novel Guru Dane, lokasi yang dimaksud ialah tempat kejadian. Tempat di mana para tokoh memainkan perannya. Seperti sebuah desa yang terdapat di bagian Lombok tengah, yakni desa "Puyung". Desa ini tidak terlalu jauh dari ibu kota kabupaten Lombok Tengah. Seperti yang digambarkan pada kutipan berikut.

Dalam hatinya ia menangis karena ingatan itu, Sumar teringat juga orang Bali yang tinggal di Puyung. Selain menguasai tanah sekitar, mereka juga banyak yang bekerja sebagai petani dan pedagang seperti orang Sasak lainnya. Mereka menunjukkan sikap yang baik. penuh persahabatan dan persaudaraan (Faris, 2011: 22).

Begitu juga halnya penggambaran lokalitas Sasak pada tempat yang tercermin di dalam novel Guru Onyeh. Seperti pada kutipan berikut.

...sedangkan mereka lahir dari keya- kinan yang hanya didongengkan oleh orang Sasak sesudah mereka. Aku juga bukan Tuan Guru Pancor. Karena ia dilahirkan dari ketaatan beragama dan berjuang untuk agama.

Iya.

Itu kalimat yang selalu diucapkan oleh Tuan Guru Pancor.

Aku mendengarnya dari orang-orang desa (Faris, 2012: 192).

Dari kutipan di atas jelas bahwa di daerah "Pancor" yang terletak di dekat ibu kota kabupaten Lombok Timur menjadi ikon pulau seribu masjid, karena di sanalah organisasi terbesar di Nusa Tenggara Barat lahir yakni Nahdlatul Wathan yang didirikan oleh TGKH. Muhammad Zainuddin Abdul Majid, pada tahun 1952.

\section{Lokalitas Sasak pada Sistem Kemasyaraka- tan}

Lokalitas Sasak yang tercermin pada sistem kemasyarakatan dalam novel Guru Dane dan Guru Onyeh initampak pada strata sosial para tokohnya. Jenis stratifikasi sosial yang dimaksud adalah seperti adanya kalangan perwangse atau bangsawan dan kalangan jajarkarang atau masyarakat biasa. Selain lokalitas sistem kemasyarakatan suku Sasak yang tercermin pada stratifikasi sosial, sistem kemasyarakatan yang terbagi ke dalam sistem kekerabatan, seperti yang terdapat pada kutipan berikut.

Maka sesudah Jero Mihram menyerahkan lontar Monyeh, cerita yang ia karang sewaktu dalam penjara di kota, kepada seorang Belanda terdidik yang ia kenal baik, ia pun memutuskan pergi berlayar. Mungkin ia merasa lebih tenang berada di Mekah dibanding di tengah-tengah orang Sasak yang tak henti-hentinya perang saudara. Jadi maaf, kalian tidak bisa bertemu dengan Jero Mihram . Akan tetapi tiga buah alQur'an itu, kami dengan senang hati memberikannya kepada kalian (Faris, 2011: 200).

Dalam istilah golongan perwangse (bangsawan) dikenal istilah gelar atau penamaan seperti kata jero yang dicetak tebal pada kutipan di atas. hal ini merupakan salah satu istilah yang disandangkan untuk para bangsawan Sasak. Jero 
sama artinya dengan bangsawan. Secara umum masyarakat Sasak menamakan para kalangan bangsawan Sasak dengan nama jero. Dalam tradisi penamaan pada masyarakat bangsawan Sasak dekenal juga nama jero bajang dan jero ayah. Jero bajang ini diperuntukkan bagi para bangsawan muda (bajang) yang belum menikah. Sedangkan jero ayah adalah nama atau istilah yang diberikan kepada para bangsawan yang sudah menikah dan sudah memiliki cucu.

\author{
Amaq. \\ Inaq. \\ Sumar bergumam lirih (Faris, 2011: \\ 19-20). \\ ... suara yang ditimbulkan ranjang reot \\ itu pu sangat aneh. \\ Kedua tangan Sumar mengejang. Ia \\ teringat ibunya. \\ Inaq. \\ Lidahnya terasa kaku memanggil ibu- \\ nya. \\ Tak ada satu sosok pun yang hadir da- \\ lam ingatannya. Semua gelap. Teling- \\ anya mendenging (Faris, 2011: 149).
}

Kata amaq dan inaq pada kutipan di atas menunjukkan bahwa pada keluarga tersebut bisa dikatakan keluarga kurenan, karena yang ada hanya tokoh Sumar, Amaq, dan Inaq. Artinya dalam keluarga tersebut merupakan keluarga inti yang terdiri dari bapak, ibu, dan anak. Istilah Amaq dan Inaq ini adalah istilah untuk menyebut bapak dan ibu pada masyarakat Sasak. Ada juga yang menyebut istilah mamiq untuk bapak dan meme untuk ibu, tetapi yang demikian hanya dipergunakan oleh orang yang bergelar bangsawan.

\section{Lokalitas Sasak pada Sistem Kepercayaan}

Telle (2009: 143) mengatakan bahwa Lombok memiliki etnik dan masyarakat yang taat beragama. Dari populasi yang ada, tercatat lebih dari 5.2 juta orang penduduk Lombok. Dari jumlah tersebut sekitar 9.2 persen masyarakat Lombok beragama Islam. Selain itu, terdapat juga etnik selain etnik Sasak, yaitu Cina, Bugis, Jawa, dan Bali. Etnik Bali di Lombok mencapai jumlah 120.000, merupakan jumlah yang besar. Akan tetapi, Bali menjadi agama yang minoritas.

Sistem kepercayaan yang ada di daerah Lombok cukup beragam, salah satunya masih ada di kalangan masyarakat suku Sasak yang mempercayai kekuatan gaib pada suatu benda.

Putu Sunarie mengangguk.

... Kamu ingin aku apakan belati ini?

Eeemmm. Aku bermaksud menghadiahkan kepada orang Belanda itu. Aku berharap Guru Dane mengisinya terlebih dahulu sehingga orang Belanda itu tertarik dan tidak berpikir panjang untuk melibatkan aku ke dalam bisnis perdagangan mereka.(Faris, 2011: 84).

Di samping itu masyarakat suku Sasak dalam memperaktekkan agama yang mereka anut, yakni agama Islam sebagai agama mayoritas, masih memiliki paham yang berbeda-beda. Ada yang mengaktualisasikan syariat Islam dengan hanya menjalankan tiga aspek dari lima rukun Islam yang ada. Aliran kepercayaan semacam ini pada masyarakat suku Sasak bernama Islam Wetu Telu. Paham ini berkeyakinan bahwa, tidak wajib ke Mekah untuk berhaji begitupun dengan berzakat. Seperti yang tergambar dalam kutipan berikut.

Itu bukti kesombongan bangsamu. Mengaku tidak perlu ke Mekah untuk melihat Ka'bah. Mereka pun membuat Ka'bah dalam ilusi. Lalu mengajarkan kepada mereka yang bodoh tentang penyesatan-penyesatan. Lacur bagi bangsamu. Mereka tumbuh dalam ilusi gaib, kemudian menjadikan kegaiban itu sebagai lambang kemanusiaan tertinggi. Padahal, itulah kebodohan sejati. Jayengrane disebut Sayyidina Hamzah. Muhammad nabi disebut lahir di Lombok (Faris, 2012: 184).

\section{Lokasitas Sasak pada Kesenian}

Menurut Wacana (2002, pp. 210) tembang merupakan suatu jenis suara vokal yang hidup di masyarakat Lombok, terutama di desadesa. Masyarakat pedesaan suku Sasak pada umumnya sebagian besar (laki-laki/perempuan) masih mengahabiskan waktu untuk bekerja di 
sawah, dan sudah menjadi tradisi turun-menurun masyrakat Sasak. Sehingga, pada momen tersebut mereka melantunkan tembang-tembang untuk mengahalau rasa lelah mereka. Adapun jenis seni suara yang lain, yakni kayak. Kayak ini di sebagian besar wilayah Lombok mengenali jenis seni suara ini. Suatu jenis suara vokal yang bergenre pantun dan bentuknya berbait-bait. Fungsi dari kayak ini untuk mengiringi instrumental suatu tarian (Wacana, 2002: 210). Di samping tembang dan kayak, masyarakat suku Sasak juga memiliki kesenian gendang beleq, yang sering digunakan oleh masyarakat dalam upacara nyongkolan.

Aku tidak pernah menduga, kita akan berakhir seperti ini.

Gugur mayang lek jelo bian.

Menah tandor bulan kemalem.

Bergugur bunga di ambang sore.

Bercahaya penuh rembulan di tengah malam.

Pemangku Sasak bertubuh kurus menembang denganbibir dilipat (Faris, 2012: 351).Sementara itu, gendang beleq terbawa emosi oleh musik dangdut Sasak remik. Seluruh pemain gendang beleq mengamuk dengan memukul lebih keras alat musik mereka. Begitu juga dengan pemain yang sedang memainkan musik gending (Faris, 2012: 339).

Dari kutipan di atas membuktikan bahwa di suku Sasak terdapat kesenian yang menjadi ciri khas daerah Lombok, yang dapat memberikan warna tersendiri bagi masyarakatnya sehingga menjadi beda dengan daerah-daerah yang lain. Namun, dibalik kekayaan tradisi seperti kesenian tersebut, masyarakat suku Sasak memiliki sejarah akulturasi kebudayaan secara besar-besaran khususnya diranah kesenian, selain yang tersebut di atas ada juga kesenian bayang yang merupakan hasil peninggalan para wali dari Jawa sebagai media penyebaran agama Islam di Lombok. Sebagaimana halnya yang disampaikan oleh Harnis (2003, p. 91) berikut.

The shadowplay of Lombok, Indonesia, wayang Sasak (wayang of the sasak people, the majority population) is not well known outside the island.
Its origins are obscure. Most reports indicate that the form entered Lombok with the comming of Javanese, sufilike Islam in the 16 century, and it was than usud to help convert the population. Stories are drawn from the serat menak (book of the menak) a cycle of the tales of Persian and Indic origin involving Amir Hamzah, the uncle prophet Muhammad, generally in his form Jayengrana (a modification of the Javanese "Jaya ing rana"...

Permainan bayang atau wayang ini merupakan salah satu akulturasi budaya Jawa pada saat "Wali Songo" menyebarkan agama Islam di Lombok.

\section{Lokalitas Sasak pada Penggunaan Bahasa}

Penggunaan bahasa Sasak sebagai cerminan lokalitas Sasak dalam novel Guru Dane dan Guru Onyeh sangat banyak. Hal ini menandakan bahwa sang pengarang tidak krisis identitas sebagai bagian dari warga masyarakat suku Sasak. Terbukti di sepanjang cerita dalam novel Guru Dane dan Guru Onyeh, pengarang menyisipkan bahasa Sasak, baik yang digunakan dalam istilah nama minuman keras, tempat penampungan air, nama benda, istilah alam, hantu, mantra, tembang, kayak, nama peralatan, dan pepatah. Demikian juga komunikasi antar tokoh kadang juga menggunakan bahasa Sasak. Berikut merupakan penggunaan bahasa Sasak yang tercermin pada dialog antar tokoh yang menggunakan bahasa "Sasak sedang".

Aku tidak tertarik dengan cerita orang menak yang pergi ke Sumbawa itu, Amak Dulajih. Lagian orang Sumbawa tidak mungkin mau serendah itu di hadapan orang Lombok. bahkan mereka jauh lebih terbukti memiliki garis silsilah dibanding orang-orang Lombok. jangan ngawur begitu, Amak Dulajih. Side disunat untuk kedua kalinya oleh orang Sumbawa, baru tahu rasa (Faris, 2012: 243).

Kata side pada kutipan di atas menunjukkan bahwa adanya tingkatan bahasa dalam bahasa Sasak. Kata side tersebut termasuk ke 
dalam bahasa Sasak sedang, karena kalau bahasa halusnya side adalah pelungguh atau pelinggih. Sedangkan bahasa biasa atau kasarnya ialah kamu, mek, dan epe yang berarti anda atau kamu. Penggunaan kata side saat berkomunikasi dengan orang yang lebih tua dari penutur. Kemudian kata pelungguh atau pelunggih digunakan saat berkomunikasi dengan orang bangsawan Sasak, sebagai bentuk penghormatan.

\section{Lokalitas Sasak pada Sistem Mata Pencahari- an Hidup}

Sistem mata pencaharian hidup merupakan cara suatu masyarakat dalam memperoleh sesuatu yang dianggap bisa membaut mereka bertahan hidup. Dalam sistem pencaharian hidup masyarakat Sasak sendiri, disesuaikan dengan kondisi geografi wilayahnya, karena di daerah Lombok merupakan wilayah subur, sehingga kebanyakan masyarakatnya bekerja sebagai petani, sebagiannya lagi menjadi pedagang.

Dalam novel Guru Dane dan Guru Onyeh, sudah tergambar jelas mengenai mata pencaharian hidup masyarakat suku Sasak yang mencerminkan lokalitas Sasak. Menjadi pembuat senjata di samping bertani sebagai cerminan lokalitas Sasak pada aspek sistem mata pencaharian terdapat dalam kutipan berikut.

Segala menjadi terbayang. Semuanya tumbuh terkenang. Sosok orang tua Sumar, yang petani Sasak asli, tetapi punya kemapuan lain sebagai pembuat senjata, baik untuk perang maupun alat pertanian, seolah-olah berdiri di hadapan Sumar. Mereka seakan-akan ingin memberikan kekuatan kepada Sumar sekaligus meyakinkan kepadanya, apa yang Sumar alami merupakan keharusan. Pada Saatnya nanti Sumar pasti mengerti (Faris, 2011: 19).

\section{Lokalitas Sasak pada Sistem Teknologi dan Peralatan}

Dalam novel Guru Dane maupun Guru Onyeh, sistem teknologi dan peralatan yang mencerminkan lokalitas Sasak banyak dijelaskan oleh pengarang. Seperti peralatan memasak, peralatan tidur, alat teransportasi, dan tempat menampung air untuk minum dan memasak. Sistem teknologi dan peralatan yang digunakan oleh masyarakat suku Sasak tergolong sederhana. Hal tersebut digambarkan dalam kutipan berikut.

Ibu, apakah makanannya belum matang?

Ibu tidak menjawab. Tangannya terus mengaduk-aduk sendok, terbuat dari batok kelapa di tempat menanak, nasi terbuat dari tanah.

Ibu, aku hanya ingin memastikan, apakah kita bisa makan malam ini? (Faris, 2012: 28).

Dari kutipan di atas jelas sekali digambarkan oleh pengarang mengenai kondisi masyarakat Sasak dalam menggunakan teknologi dan peralatan. Peralatan memasak masyarakat Sasak menggunakan tungku yang terbuat dari tanah liat. Bahan bakarnya cukup menggunakan kayu. Kemudian sendok yang digunakan untuk mengaduk masakan terbuat dari batok kelapa. Cukup mencerminkan kesederhanaan. Sehingga, masyarakat Sasak untuk memenuhi kehidupannya, mereka tidak perlu menggunakan peralatan yang mengharuskan mereka mengeluarkan uang. Mereka cukup membuat peralatan sendiri. Selanjutnya lokalitas Sasak yang tercermin pada peralatan tidur. Berikut gambaran dalam kutipan.

Melihat Guru Dane semacam itu, ia kemudian membaringkan tubuh Guru Dane pada sebuah tikar pandan yang sudah lusuh. Berlubang dan sobek di masing-masing segi. Sudut tikar pun memerlihatkan bentuk yang lapuk. Satu tanda terbaca, mereka orang miskin di tengah ribuan kemiskinan lainnya (Faris, 2011: 4).

Berdasarkan kutipan di atas, masyarakat Sasak menjadikan anyaman daun pandan menjadi kasur tempat tidurnya. Peralatan tidur yang sederhana ini berbahan cukup sederhana, yakni terdiri dari daun pandan yang sudah melalui proses penegeringan menggunakan sinar matahari. Sebagian besar masyarakat Sasak bisa menganyam daun pandan ini menjadi tikar. Namun, akibat perkembangan zaman dan pergeseran nilai, maka masyarakat sudah jarang memanfaatkan daun pandan sebagai alas 
tidurnya. Sehingga, tradisi yang baik ini sudah menghilang dari kehidupan orang Sasak. Hanya di daerah tertentu saja yang masih mengembangkan kerajianan menganyam daun pandan tersebut. Padahal peralatan tidur seperti daun pandan ini sangat nyaman untuk dijadikan alas tidur, karena dingin yang diciptakan oleh lantai tidak bisa tembus, sehingga menjadikan badan tetap hangat di saat tidur.

Selanjutnya teknologi dan peralatan masyarakat Sasak yang teraktualisaskan pada alat transportasi yakni cidomo. Cidomo ini merupakan becak yang ditarik oleh seekor kuda dan dikendalikan oleh sopir yang disebut kusir. Alat transportasi tradisional Sasak ini memiliki kemiripan dengan andong yang ada di daerah Jawa. Alat transportasi ini biasanya digunakan oleh para ibu-ibu yang mahu ke pasar. Hal tersebut digambarkan oleh pengarang dalam kutipan berikut.

Perlahan aku mendekati parkiran cidomo, takut pedagang itu mengetahui aku sebelum bisa mendekatinya. Kuda tarik terlihat gelisah, dan kusir segera memberikan aba-aba kepada kudanya agar lebih tenang. Sekitar lima meter dari cidomo, aku memiliki kesempatan segera mendekat ke pedagang (Faris, 2012: 311).

Fungsi Lokalitas Sasak dalam Membangun Cerita Secara Keseluruhan dalam Novel Guru Dane dan Guru Onyeh

Fungsi merupakan sesuatu yang bermanfaat dan berpengaruh terhadap sesuatu, berupa pelengkap yang melengkapi sesuatu yang belum lengkap dan masih terlihat pincang. Lokalitas Sasak, yang dalam hal ini berfungsi melengkapi cerita, memberikan suasana yang berbeda, kelihatan menarik, dan kekhasan terhadap penciptaan karya sastra secara total. Lokalitas Sasak merupakan deskripsi kondisi yang mampu menciptakan suasana tertentu bagi para pembaca. Pembaca yang memiliki daya imajinasi dan kepekaan emosional yang tinggi, tentu akan bisa menangkap kondisi atau suasana yang ditawarkan oleh pengarang. Misalkan suasana haru, sedih, dan bahkan bangga, di saat menemukan penceritaan mengenai kondisi sebuah daerah, yang bisa saja sama dengan apa yang dia alami di daerah tempat tinggalnya.

Lokalitas Sasak mampu memberikan warna dalam novel Guru Dane dan Guru Onyeh. Kecerdikan sang pengarang pun teruji dalam hal penggunaan diksi. Sebagai seorang yang berlatar belakang suku Sasak, pengarang mampu menyuguhkan unsur lokal Sasak secara total, baik dari segi penggunaan bahasa, penentuan latar, sampai kepada pemilihan nama-nama tokoh yang mempunyai unsur lokalitas Sasak. Novel Guru Dane dan Guru Onyeh mengandung aspek dan unsur lokal yang begitu kuat. Terlihat pada penggunaan bahasa Sasak yang diselipkan oleh pengarang di sepanjang cerita. Unsur-unsur lokalitas seperti penggunaan bahasa, kesenian, dan latar ini mengambil bagian yang teramat sentral sebagai pembangun cerita secara keseluruhan.

Lokalitas Sasak yang dipaparkan yang tercermin dalam kutipan kedua novel Salman Faris, sebagai fungsi dalam membangun cerita secara keseluruhan. Sebenarnya kutipan yang tercermin pada semua wujud lokalitas Sasak di atas mewakili sebagai fungsi dalam membangun cerita secara keseluruhan. Karena apa yang dipaparkan pada wujud lokalitas Sasak di atas merupakan unsur yang akan di paparkan dan dibahas pada bagian fungsi lokalitas Sasak berikut ini. Akan tetapi kutipan yang akan dipaparkan pada bagian berikut hanya beberapa saja bagian kutipan saja, sebagai perwakilan dan pelengkap, karena sekali lagi apa sudah dipaparkan pada bagian wujud lokalitas Sasak di atas pada dasarnya sama, yakni unsur lokasi, nama-nama tokoh, penggunaan bahasa, dan sebagainya, yang secara keseluruhan memiliki fungsi sebagai pembangun cerita secara keseluruhan di dalam novel Guru Dane maupun Guru Onyeh.

\section{SIMPULAN}

Mengacu dari apa yang ada pada rumusan masalah, hasil, dan pembahasan penelitian terhadap upaya pengungkapan wujud lokalitas Sasak dalam novel Guru Dane dan Guru Onyeh, pengungkapan fungsi lokalitas Sasak dalam membangun cerita secara keseluruhan pada novel Guru Dane dan Guru Onyeh 
karya Salman Faris. Selanjtnya akan dipaparkan secara singkat, padat, dan jelas pada simpulan berikut.

Lokalitas Sasak dalam novel Guru Dane dan Guru Onyeh karya Salman Faris, bisa dikatakan cukup banyak dan dominan. Pengungkapan unsur-unsur lokalitas tersebut menjadikan novel memiliki karakter dan bermakna bagi para pembaca. Penjabaran lokalitas Sasak dalam novel Guru Dane dan Guru Onyeh ini terdiri atas: (1) lokasi atau tempat, (2) sistem kemasyarakatan, (3) sistem kepercayaan, (4) kesenian Sasak, (5) penggunaan bahasa Sasak, (6) sistem mata pencaharian hidup, dan (7). sistem teknologi dan peralatan. Ketujuh unsur tersebut termasuk ke dalam wujud lokalitas Sasak. Pada pembahasan yang kedua terdapat fungsi lokalitas Sasak yang terdapat pada novel Guru Dane dan Guru Onyeh sebagai pembangun cerita secara keseluruhan, di antaranya latar tempat, diksi/pilihan kata (penggunaan bahasa Sasak), dan nama-nama tokoh. Ketiga aspek tersebut yang dominan sebagai pembangun cerita dalam novel selain aspek-aspek yang lain.

Penelitian terhadap lokalitas Sasak dalam novel Guru Dane dan Guru Onyeh ini hanya untuk mengungkap dan mendeskripsikan lokalitas Sasak yang terungkap dalam novel, dan juga untuk melihat fungsi penggunaan lokalitas Sasak dalam membangun cerita secara menyeluruh. Oleh karena itu, sebagai saran terhadap para peneliti supaya bisa meneliti aspek-aspek budaya lokal yang lain yang terkandung dalam novel-novel yang memiliki warna lokal menggunakan sumber penelitian yang lebih banyak, dan rentang waktu yang lebih panjang, karena di dalam penelitian ini sumber data yang digunakan hanya dua novel, yakni Guru Dane dan Guru Onyeh, sehingga wajar kalau dalam penelitian ini menemukan hasil yang kurang lengkap. Kalau bisa gunakanlah subjek penelitian bentuk sastra yang lain, seperti cerpen, puisi, atau bahkan drama sehingga hasil penelitian menjadi lebih lengkap.

Selain saran yang ditujukan bagi para peneliti, saran ini juga ditujukan kepada beberapa pihak sebagai berikut.

Budayawan, sastrawan, serta pemerhati budaya lainnya untuk terus berinovasi, berkreasi, dan berkarya dalam hal menumbuh kembangkan kepedulian masyarakat tentang budaya lokal, yakni budaya lokal Sasak lewat karya-karya yang bernuansa lokal. Kemudian pelatihan-pelatihan, sosialisasi, mengenai pentingnya melestarikan budaya lokal sebagai salah satu jati diri bangsa. Diharapkan juga bagi para budayawan, sastrawan untuk terus menggawangi ranah budaya lokal yang kita miliki serta terus memperhatikan perkembangannya. Karena dengan adanya kepedulian seperti ini, maka tidak menutup kemungkinan akan tumbuh rasa cinta budaya lokal dalam diri masyarakat, karena mereka setidaknya diberikan pemahaman dan pengawalan.

Orang tua dan masyarakat agar senantiasa mendidik dan memberikan pemahaman mengenai tata cara, tata krama, serta penanaman nilai budaya lokal sedari anak-anak masih kecil. Sehingga setelah mereka besar tidak mudah dipengaruhi dengan globalisasi, dan terus mengawal anak-anak untuk tidak terlalu larut dengan gaya barat yang terkesan glamor dan dapat membahayakan karakter anak.

Guru di sekolah agar bisa memberikan pemahaman budaya disela-sela pemberian materi pengetahuan umum. Sebisa mungkin para guru memperkenalkan budaya lokal yang dimiliki oleh peserta didik, sehingga tidak membuat mereka merasa asing di daerahnya sendiri, karena tidak adanya pengetahuan tentang adat dan tradisi yang berlaku di daerahnya. Bagaimanapun juga hal ini penting terhadap pola pikir serta karakter anak. Sehingga akan berpengaruh terhadap perilaku kesehariannya. Tanamkan pada diri peserta didik nilai-nilai budaya lokal yang amat luhur, terutama tentang kesopanan.

Pemerintah dalam hal ini dinas pendidikan dan kebudayaan Provinsi Nusa Tenggara Barat, untuk selalu mengintruksikan kepada semua elemen yang terkait tentang pentingnya melestarikan budaya daerah. Kemudian elemen-elemen di bawahnya sebisa mungkin untuk mensosialisasikan kepada masyarakat tentang hal tersebut. Kemudian yang paling utama ialah, dimohon kepada dinas kebudayaan untuk memberikan perhatian serta apresiasi terhadap masyarakat yang memiliki kesadaran untuk mahu mengangkat serta memperkenalkan budaya lokal Sasak supaya bisa menasional, 
lewat karya-karya yang mereka ciptakan dan kembangkan, seperti karya-karya fiksi (novel maupun puisi), lewat seni tari, drama, maupun musik tradisional, untuk sebisa mungkin didukung secara moril ataupun materil, supaya gaung budaya Sasak semakin besar dan bisa dikenal oleh masyarakat nasional maupun internasional.

\section{DAFTAR PUSTAKA}

Abrams, M.H. 1981. A Glossary of Literary Terms. New York: Holt, Rinehart and Winston.

Berns, R.M. 2004. Child, Family, School, Community: Socialization and Support. Sixth edition. Australia, Canada, Mexiko, Singapore, Spain, United Kingdom, United State: Thomson Wodsworth.

Denzin \& Lincoln. 2005. Qualitative Research. Third Edition. Thousand Oaks, London, New Delhi: Sage Publications.

Faris, S. 2011. Guru Dane. Lombok: STKIP Hamzanwadi Press.

Faris, S. 2012. Guru Onyeh. Lombok: STKIP Hamzanwadi Press.

Geertz, C. 1973. The Interpretation of Cultures. New York: Basic Books, Inc., publisher.

Hartono. 2015. Warna Lokal Jawa dalam Novel Indonesia Periode 1980-1995. Disertasi Doktor, Universitas Gadjah Mada.

Kuntowijoyo. 1987. Pembentukan Simbol di Kalangan Santri, dalam Budaya dan Masyarakat. Yogyakarta: Tiara Wacana.

Ma'arif, A.S. 2015 Islam Dalam Bingkai Keindonesian dan kemanusiaan. Bandung: Penerbit Mizan.

Moleong, L.J. 2008. Metode Penelitian Kualitatif. Bandung: PT Remaja Rosdakarya.
Pradopo, R.D. 1987. Pengkajian Puisi. Yogyakarta: Gadjah Mada University Press.

Ratna, N.K. 2011. Antropologi Sastra: Peranan Unsur-unsur Kebudayaan dalam Proses Kreatif. Yogyakarta: Pustaka Pelajar.

Rosidi, A. 1985. Kapankah Kesusastraan Indonesia Lahir?. Jakarta: Gunung Agung.

Salam, S. 1992. Lombok Pulau Perawan: Sejarah dan Masa depannya. Jakarta: Kuning Mas.

Sumadi, I.W.S., I.G.N Jayanti., \& A.A. Rai Geria. 2013. Tradisi Nyongkol dan Eksistensinya di Pulau Lombok. Yogyakarta: Penerbit Ombak.

Sayuti, Suminto A.. 2011. Pengembangan budaya dan potensi lokal. Pokok-pokok Pikiran untuk Seminar Nasional tentang Pengembengan Pendidikan Karakter Bangsa Berbasis Kearifan Lokal untuk Menghadapi Tantangan Global oleh Lembaga Penelitian UNY, di Universitas Negeri Yogyakarta.

Sutarto, A. 2004 Pendekatan Kebudayaan: Wacana Tandingan Untuk Mendukung Pembangunan di Provinsi Jawa Timur. Jember: Kompyawisda.

Telle, K. 2009. Dharma Power: Searching for Security in Post-New Order Indonesia, Social Analysis, 53,1;141.

Wacana, L. 2002. Sejarah Daerah Nusa Tenggara Barat. Mataram, Februari 1988: Departemen Pendidikan dan Kebudayaan.

Wiyatmi. 2013. Sosiologi Sastra Teori dan Kajian Terhadap Sastra Indonesia. Yogyakarta: Kanwa Publisher. 